\title{
Sensitivity of peatland litter decomposition to changes in temperature and rainfall
}

\section{Article}

\section{Accepted Version}

Creative Commons: Attribution-Noncommercial-No Derivative Works 4.0

Bell, M. C., Ritson, J. P., Verhoef, A., Brazier, R. E., Templeton, M. R., Graham, N. J. D., Freeman, C. and Clark, J. M. (2018) Sensitivity of peatland litter decomposition to changes in temperature and rainfall. Geoderma, 331. pp. 2937. ISSN 0016-7061 doi: https://doi.org/10.1016/j.geoderma.2018.06.002 Available at https://centaur.reading.ac.uk/78106/

It is advisable to refer to the publisher's version if you intend to cite from the work. See Guidance on citing.

Published version at: https://doi.org/10.1016/j.geoderma.2018.06.002

To link to this article DOI: http://dx.doi.org/10.1016/j.geoderma.2018.06.002

Publisher: Elsevier

All outputs in CentAUR are protected by Intellectual Property Rights law, including copyright law. Copyright and IPR is retained by the creators or other copyright holders. Terms and conditions for use of this material are defined in the End User Agreement.

\section{www.reading.ac.uk/centaur}

\section{CentAUR}


Central Archive at the University of Reading

Reading's research outputs online 


\section{Sensitivity of peatland litter decomposition to changes in}

\section{2 temperature and rainfall}

4 AUTHORS AND AFFILIATIONS

$5 \quad$ Michael C. Bell ${ }^{\mathrm{a}},{ }^{*}$, Jonathan P. Ritson ${ }^{\mathrm{b}, \mathrm{c}}$, Anne Verhoef $^{\mathrm{a}}$, Richard E. Brazier ${ }^{\mathrm{d}}$, Michael

6 R. Templeton ${ }^{c}$, Nigel J.D. Graham ${ }^{c}$, Chris Freeman ${ }^{\mathrm{e}}$, Joanna M. Clark ${ }^{\mathrm{a}}$

$7 \quad{ }^{a}$ Soil Research Centre, Department of Geography and Environmental Science, School

8 of Archaeology, Geography and Environmental Science, The University of Reading,

9 Whiteknights, PO Box 227, Reading RG6 6AB, UK

10 brantham Institute for Climate Change, Imperial College London, South Kensington,

11 London SW7 2AZ, UK

$12{ }^{\mathrm{c}}$ Department of Civil and Environmental Engineering, Imperial College London, South

13 Kensington, London SW7 2AZ, UK

$14{ }^{\mathrm{d}}$ Geography, College of Life and Environmental Sciences, University of Exeter, EX4

15 4RJ, UK

16 e Wolfson Carbon Capture Laboratory, School of Biological Sciences, Bangor

17 University, Bangor, Gwynedd LL57 2UW, UK

$18{ }^{*}$ Corresponding author: Soil Research Centre, Department of Geography and

19 Environmental Science, School of Archaeology, Geography and Environmental Science, The

20 University of Reading, Whiteknights, PO Box 227, Reading RG6 6AB, UK. E-mail address:

21 m.c.bell@pgr.reading.ac.uk 


\section{Abstract}

Changes to climate are projected over the next 50 years for many peatland areas. As decomposition of peat-forming vegetation is likely to be intrinsically linked to these changes in

27 climate, a clear understanding of climate-peat dynamics is required. There is concern that

28 increased temperature and decreased precipitation could increase the rate of decomposition

29 and put the carbon sink status of many peatlands at risk, yet few studies have examined the

30 impact of both climatic factors together. To better understand the sensitivity of peatland

31 decomposition to changes in both temperature and precipitation and their interaction, we

32 conducted a short-term laboratory experiment in which plant litters and peat soil were

33 incubated, in isolation, in a factorial design. Treatments simulated baseline and projected

34 climate averages derived from the latest UK climate change projections (UKCP09) for Exmoor,

35 a climatically marginal peatland in SW England. Regular carbon dioxide flux measurements 36 were made throughout the simulation, as well as total mass loss and total dissolved organic

37 carbon (DOC) leached. The largest effect on carbon loss in this multifactor experiment was 38 from substrate, with Sphagnum/peat releasing significantly less $\mathrm{C}$ in total during the 39 experiment than dwarf shrubs/graminoids. Climate effects were substrate specific, with the

40 drier rainfall treatment increasing the DOC leaching from Calluna, but decreasing it from

41 Sphagnum. Partitioning between $\mathrm{CO}_{2}$ and DOC was also affected by climate, but only for the

42 peat and Sphagnum samples, where the future climate scenarios (warmer and drier) resulted

43 in a greater proportion of $\mathrm{C}$ lost in gaseous form. These results suggest that indirect effects of

44 climate through changes in species composition in peatlands could ultimately turn out to be

45 more important for litter decomposition than direct effects of climate change from increased

46 temperatures and decreased rainfall.

$47 \quad$ Keywords: decomposition; Exmoor; blanket peat; uplands; DOC; UK 
49 1. Introduction

50 Northern peatlands are an important carbon store, holding around one third of the 51 global soil carbon stock (Gorham, 1991). For peatlands to accumulate organic matter, and thus 52 sequester carbon from the atmosphere, the overall loss of carbon from the system through 53 the combined decomposition of plant litter and peat must be lower than C input via litter 54 production and vascular plant root exudation (Frolking et al., 2010; Limpens et al., 2008). 55 Decomposition is the breakdown of organic matter. It can be due to one or a number of 56 physical, chemical or biological processes. Carbon dioxide $\left(\mathrm{CO}_{2}\right)$, dissolved organic carbon 57 (DOC), nutrients and stable hummus are among the principal final products of decomposition 58 (Bragazza et al., 2009). Carbon is primarily lost as $\mathrm{CO}_{2}$ in peatlands (Billett et al., 2010).

59 However, additional losses in the form of methane $\left(\mathrm{CH}_{4}\right)$, produced during anaerobic 60 decomposition, and DOC to aquatic systems can be an important component of the peatland 61 carbon balance in some areas (Köehler et al., 2011). The speed and final product of the 62 decomposition process is dependent on the chemistry of the organic matter, and the 63 environment in which it decomposes (Limpens et al., 2008).

64 Understanding how peat and plant litter decomposition could be affected by climate 65 change, specifically changes in temperature and rainfall, is key to an improved understanding 66 of how the peatland carbon source/sink status could change during the $21^{\text {st }}$ century. Northern 67 peatlands are typically dominated by remains of mosses of the genus Sphagnum, a bryophyte 68 (Turetsky, 2003). Sphagnum has played an important role in peatlands becoming such a large

69 carbon sink. Not only does the recalcitrance of its litter mean that it keeps $C$ in the system for

70 longer, but the presence of Sphagnum maintains acidic, nutrient poor conditions which make

71 it difficult for plants with more labile litter to establish themselves (van Breemen, 1995). 
72 Climate change may alter vegetation types in peatlands with vascular plants becoming more

73 dominant (Buttler et al., 2015; Dieleman et al., 2015; Fenner et al., 2007; Weltzin et al., 2003).

74 However, many ongoing catchment management programmes aim to encourage Sphagnum

75 species over vascular plants as part of peatland restoration programmes (Grand-Clement et

76 al., 2013).

While some authors have studied the effects of climate variables on the treatability of

78 water from different peatland plant species (e.g. Ritson et al., 2014; Tang et al., 2013), little

79 work has so far been conducted on the total flux of carbon and the partitioning between

80 gaseous and fluvial losses from different peatland plant species. This partitioning is an

81 important parameter to include in carbon cycle models, particularly for climate change

82 modelling as there is likely to be a lag between DOC release from the soil and its incorporation

83 into the atmospheric pool, as in-stream processing can lead to the temporary storage of $\mathrm{C}$

84 within the aquatic system (Hope et al., 1994). An understanding of partitioning of carbon

85 losses between aquatic and gaseous fractions from different vegetation sources is also

86 important for predicting whether catchment management programmes aimed at restoring

87 certain species have the desired holistic effects of improving drinking water quality (including

88 enhanced $\mathrm{C}$ sequestration) and do not result in environmental problem-shifting.

89 Decomposition of litters in the field is traditionally measured using the litter bag

90 technique (Bragazza et al., 2009; Wieder and Lang, 1982). Litter of a known mass is enclosed

91 in mesh bags with openings large enough for decomposers to access the food source, but

92 small enough to prevent the physical loss of litters. Samples are incubated in the field, either

93 on, or just below the soil surface (Johnson and Damman, 1991; Moore et al., 2007) and

94 decomposition rate is quantified via mass loss or changing nutrient quotients of the litter

95 (Keuskamp et al., 2013). In situ litter decomposition studies, using this technique, have 
96 suggested multiple drivers for increased decomposition rates in peatland systems including:

97 elevated nutrient additions (Bubier et al., 2007), water-table drawdown (Straková et al., 98 2012), litter quality (Limpens and Berendse, 2003) and temperature (Moore et al., 2007).

99 However, these field-based studies are limited to a single measure of decomposition; mass

100 loss. Mass loss gives a valuable measure of net decomposition, which can be useful for

101 comparing between litters, but does not provide information on the final product of the

102 decomposition process. Carbon dioxide and DOC not only represent different flux pathways

103 (gaseous versus aquatic), but can also be indicative of different processes and stages of

104 decomposition. $\mathrm{CO}_{2}$ is in effect representative of fully utilised carbon, whereas DOC could be

105 stored in the peat column or utilised by microbes and exported to the atmosphere via 106 respiration (Pastor et al., 2003; Turetsky, 2003).

107 Laboratory incubations of peatland litters to examine the relationship between 108 decomposition and climate have been limited to date. Studies that have been conducted have

109 tended to concentrate on a single measure of decomposition, have focussed solely on peat

110 rather than vegetation, or have just looked at one environmental variable, such as

111 temperature (e.g. Neff and Hooper 2002; Moore et al. 2008) or water table (e.g. Freeman et

112 al. 1993), in isolation. The effect of interactions between changes in temperature and rainfall

113 on the decomposition of peatland litter is not currently well understood (Breeuwer et al.,

114 2008). A gradient based mesocosm study measured increased $C$ soil respiration in mesocosms

115 transplanted to a warmer, drier location (Bragazza et al., 2016). However, isolating the effects

116 of climatic variables such as temperature and rainfall from other confounding variables can

117 be difficult in the field as these factors naturally co-vary. It is also difficult to separate the

118 effects on different litters and measure the relative decomposition from different sources in

119 the field or in intact mesocosms. To address this, previous studies have incubated soils or 
120 litters from wetland sites in isolation, notably Moore and Dalva (2001), Neff and Hooper

121 (2002) and Wickland et al. (2007). This was the approach taken here.

122 A better understanding of the sensitivity of different peatland litters to changes in

123 temperature and rainfall regime is needed to enable predictions of the impact of climate

124 change on the stability of peatland carbon stocks, and to support better parameterisations of

125 models that simulate past, current and future climate (Frolking et al., 2010; Smith et al., 2010).

126 Therefore, the objectives of this research were as follows: (1) assess how litter decomposition

127 rates varied between common ombrotrophic peatland plant species (Calluna vulgaris, Molinia

128 caerulea, Sphagnum moss, and mixed litter) compared to peat; (2) determine the relative

129 importance (or partitioning) of gaseous (i.e. $\mathrm{CO}_{2}$ ) versus aquatic (DOC) fluxes during

130 decomposition with respect to plant species and peat; (3) evaluate the importance of

131 simulated temperature and rainfall changes on controlling total decomposition, $\mathrm{C}$ fluxes and

132 partitioning between $\mathrm{CO}_{2}$ and DOC. This final objective links to another study (Ritson et al.,

133 2014), which used the same experimental treatments to examine the impact of climate

134 change on the treatability (for potable water supply) of dissolved organic matter.

136 2. Methods

137 2.1. Field site and sample collection

138 In the south-west UK, blanket peat covers large parts of the upland areas and 139 constitute an important store of C (Parry and Charman, 2013). These blanket peatlands 140 represent the southern-most blanket peat in the UK and are considered climatically marginal 141 (Clark et al., 2010). The shallow peat of Exmoor was heavily damaged by intensive drainage 142 during the $19^{\text {th }}$ and $20^{\text {th }}$ centuries, and recent efforts have been made to restore large areas 
143 through a programme of ditch blocking (Grand-Clement et al., 2014, 2013). The field sites are

144 dominated by Molinia caerulea (purple moor grass) (Gatis et al., 2015) and are classified as UK

145 National Vegetation Classification M25: Molinia caerulea - Polentilla erecta mires (Rodwell, 146 1991). Paleoecological studies indicate that purple moor grass expansion corresponds with 147 the industrial revolution and prior to this, Sphagnum was more dominant species within this 148 region (Chambers et al., 1999). Exmoor typically receives precipitation of around 1800-2600 $149 \mathrm{~mm} \mathrm{yr}^{-1}$ with mean winter and summer temperatures of between $4.5-5.5^{\circ} \mathrm{C}$ and $10-12{ }^{\circ} \mathrm{C}$, 150 respectively (Met Office, 2014). Exmoor receives a relatively high input of nutrients through 151 atmospheric deposition, and the mean deposition of total nitrogen and oxidised sulphur for 152 the period 2008-2012 was estimated to be 15.5-16.16 $\mathrm{kg} \mathrm{N} \mathrm{h}^{-1} \mathrm{yr}^{-1}$ and 4.41-4.86 $\mathrm{kg} \mathrm{S} \mathrm{h}^{-1} \mathrm{yr}^{-}$ $153{ }^{1}$, respectively (DEFRA, 2015).

154 Samples of vegetation and peat were collected from two catchments, Aclands $\left(51^{\circ}\right.$

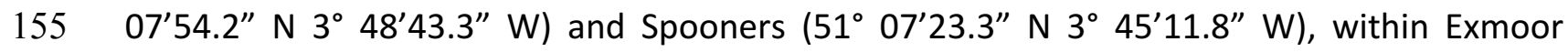
156 National Park, UK, during July 2013. A further description of these field sites, including maps, 157 can be found in Grand-Clement et al. (2014) and Luscombe et al. (2015). Five different 158 substrates were collected: Calluna, Molina and Sphagnum, mixed litter and peat. Fresh leaves 159 and branches were collected from Calluna vulgaris and Molinia caerulea, avoiding any plants 160 which had been partially eaten by herbivores. Mixed litter (predominantly Molinia caerulea 161 but also some Eriphorum vaginatum, both at the early stages of decomposition) was collected 162 from the bog surface. Intact Sphagnum spp. sods (entire plants) were collected from the 163 centre of stands and peat was collected from the top ca. $30 \mathrm{~cm}$ of the soil profile using a screw 164 auger. The samples were transported back to the laboratory in cool boxes within 8 hours of 165 collection, and stored at $4{ }^{\circ} \mathrm{C}$ prior to their preparation. Sample collection is described fully in 166 Ritson et al. (2014). 
$168 \quad$ 2.2. Sample preparation

169 Samples from each vegetation class (Calluna vulgaris, Molinia caerulea, mixed litter

170 and Sphagnum spp.), were cut into $2-3 \mathrm{~cm}$ sections and mixed thoroughly within their class.

171 Any material not from the target group was removed. Once sorted, cut and homogenised, the

172 vegetation samples were left to air-dry in the laboratory to constant mass (Moore et al., 2007).

173 The structure of peat is permanently altered when dried, becoming hydrophobic (Holden and

174 Burt, 2002). For this reason, the peat was treated differently to the other substrates and was

175 kept refrigerated and at field moist conditions prior to the experiment.

176 Air-dried sub-samples of each plant species and field moist peat $(n=5)$ were oven dried at 70

$177{ }^{\circ} \mathrm{C}$ for $24 \mathrm{~h}$ to determine an air-dry to oven-dry conversion factor. This conversion factor was

178 applied to estimate the oven-dry weight of samples at the beginning of the simulation. These

179 oven-dry samples were analysed for litter quality (see methods below; Table 1).

$181 \quad$ 2.3. Experimental design

182 2.3.1. Experimental set up

183 Polypropylene Buchner funnels (Thermo Scientific, USA) were filled with

184 approximately $2 \mathrm{~g}$ dry-weight of air-dry vegetation or $10 \mathrm{~g}$ homogenised peat. The stem of the

185 funnel was packed with acid washed glass wool to ensure no loss of particulates, and each

186 Buchner funnel was placed above an amber-glass bottle to collect leachate, for separate 187 analysis (see Ritson et al., 2014). The climate control facilities comprise two versatile 188 environmental test chambers (Panasonic MLR-352H). The incubators were set to cycle 189 between $12 \mathrm{~h}$ at the mean daily maximum and $12 \mathrm{~h}$ at the mean daily minimum temperature. 
190 Deionised water was applied in amounts equivalent to the monthly rainfall, with a dispenser

191 set to the required volume based on the area of the Buchner funnel top. This was applied

192 gradually and evenly, over approximately 30 seconds, taking care not to disturb the samples.

\section{2.3.2. Experimental design}

The experiment was set up as a factorial ANOVA design, where substrate, temperature and rainfall were the treatment factors in a $5 \times 2 \times 2$ design. Five replicates of each treatment were conducted, giving a total of 100 samples (see Ritson et al., 2014). Climate treatments were based on (i) baseline (1961-1990; Met Office, 2013) mean minimum and mean maximum

199 daily temperature and mean rainfall totals for July and August for Exmoor National Park, UK,

200 and (ii) a projection from the UKCP09 high emissions scenario for 2080s (2070-2100). All four

201 possible combinations of baseline and projected temperature and rainfall were applied as

202 treatments. Mean minimum daily temperatures were set to $11.0^{\circ} \mathrm{C}\left( \pm 0.3^{\circ} \mathrm{C}\right.$ for test chamber

203 error) for the baseline, and $15.4^{\circ} \mathrm{C}\left( \pm 0.3^{\circ} \mathrm{C}\right)$ for the UKCP09 treatment. Mean maximum daily

204 temperatures were set to $18.2^{\circ} \mathrm{C}\left( \pm 0.3^{\circ} \mathrm{C}\right)$ for the baseline treatment and $23.7^{\circ} \mathrm{C}\left( \pm 0.3^{\circ} \mathrm{C}\right)$ for

205 the UKCP09 treatment. Rainfall totalled 100.9 and $117.5 \mathrm{~mm}$ for the baseline treatment for

206 July and August, respectively, and 75.4 and $67.2 \mathrm{~mm}$ for the UKCP09 treatment. Overall, this

207 was equivalent to a ca. $5.0^{\circ} \mathrm{C}$ increase in temperature and ca. $35 \%$ decrease in rainfall for the

208 UKCP09 treatments. The relative humidity (to program the test chambers) and number of rain

209 days were set at mean values from the baseline period for all samples (for relative humidity:

$21080 \%$ in July, 79 \% in August; for rain days: 12 in July and 14 in August). The rainfall total for

211 each month was split evenly between the rain days (resulting in irrigation amounts ranging

212 between $4.2 \mathrm{~mm}$ and $8.4 \mathrm{~mm}$ per event, or 19 and $38 \mathrm{ml}$, depending on treatment and month), 
213 and the amounts were applied every 2-4 days. The conversion from $\mathrm{mm}$ to $\mathrm{ml}$ was based on

214 the area of the funnel.

215

216 2.4. Measurements

217 2.4.1. Carbon dioxide evolution

218 At eight points during the experiment (on days 2, 7, 10, 17, 31, 45, 50, and 60 after the

219 start of the incubation) samples were analysed for $\mathrm{CO}_{2}$ efflux. Samples were taken out of the

220 incubators individually and the top part of the Buchner funnel, containing the sample, was

221 removed and placed into an airtight container (Lock\&Lock, South Korea) which was connected

222 to an infra-red gas analyser, IRGA (8100A, LI-COR, USA). Samples were removed for

223 measurement in a random order to avoid the introduction of systematic measurement error.

224 Observations with the IRGA lasted for 2 minutes during which time the concentration of $\mathrm{CO}_{2}$

225 in the chamber (water vapour compensated) was measured every second, and the samples

226 were out of the incubators for a maximum of 5 minutes. The rate of change in $\mathrm{CO}_{2}$

227 concentration in the headspace during the 2-minute measurement period was used to

228 calculate the instantaneous flux by applying a linear regression. The IRGA system was allowed

229 to purge for a minute between samples, and a 30 second deadband (a period where the IRGA

230 is running without the measurements being used in the flux estimate) was introduced at the

231 beginning of each measurement to allow for adequate mixing of air in the headspace. The $\mathrm{CO}_{2}$

232 time series for each sample was analysed separately, and the deadband was adjusted where

233 necessary. All flux estimates were derived from a minimum of 60 consecutive $\mathrm{CO}_{2}$

234 concentration measurements (i.e. 60 seconds). Individual flux estimates were converted to

$235 \mathrm{mg} \mathrm{CO}{ }_{2}-\mathrm{g} \mathrm{C}^{-1}$ day $^{-1}$. Cumulative $\mathrm{CO}_{2}$ flux over the course of the two month experiment was 
236 calculated for each sample based on a linear interpolation of fluxes between the successive

237 measurements (Neff and Hooper, 2002), expressed as $\mathrm{mg} \mathrm{CO}_{2}-\mathrm{C} \mathrm{g} \mathrm{C}^{-1}$.

239 2.4.2. Dissolved organic carbon

240 DOC analysis was performed on the cumulative leachate collected at the end of the

241 simulation period. Samples were filtered through a GF/F filter (Whatman, UK) with a nominal

242 pore size of $0.7 \mu \mathrm{m}$, acidified to $\sim \mathrm{pH} 2$ with $\mathrm{HCl}$ and stored at $4^{\circ} \mathrm{C}$ prior to analysis. Organic

243 carbon content was measured as non-purgeable organic carbon (NPOC) using a total organic

244 carbon analyser (Shimadzu TOC-V, Japan). Calibration and quality control checks were run

245 daily from freshly prepared standards and samples were analysed within one week of the end

246 of the simulation. Organic carbon concentration $\left(\mathrm{mg} \mathrm{L}^{-1}\right)$ was converted to DOC leached $(\mathrm{mg})$

247 based on the volume of leachate collected. As temperature and rainfall treatment affected

248 the volume of sample collected, this was then reported as $\mathrm{mg} \mathrm{DOC}-\mathrm{C} \mathrm{g} \mathrm{C}$, based on the

249 starting dry mass and initial C content of each sample.

251 2.4.3. Mass loss

252 At the end of the two-month incubation period, samples were removed from the

253 incubators, dried at $70{ }^{\circ} \mathrm{C}$ for $48 \mathrm{~h}$ and weighed. $\mathrm{C}$ loss was estimated based on the starting 254 mass and starting $C$ content, as well as the end mass and end $C$ content. This was expressed 255 as $\mathrm{mgC} \mathrm{g} \mathrm{C}^{-1}$. 


\subsection{Litter quality analysis}

258 The oven-dry subsamples from the beginning, and all samples from the end of the

259 experiment were ground using a laboratory disc mill with an agate barrel (Tema Machinery

260 Ltd, UK) and analysed for total C and N (Thermo FLASH 2000 elemental analyser). The handling

261 and analysis of samples were undertaken together with reference material (Pahokee Peat,

262 International Humic Substances Society) in order to verify the calibration and quality of the

263 results. Subsamples from the start of the experiment were also analysed for C character using

264 nuclear magnetic resonance (NMR) analysis. Cross polarisation-magic angle spinning (CP-

$265 \mathrm{MAS}){ }^{13} \mathrm{C}$ NMR analysis was undertaken at the University of Reading chemical analysis facility

266 (CAF) on a Bruker AV500 instrument based on the method of Wong et al. (2002). This

267 technique is used widely in environmental studies and is good for looking at relative changes

268 in carbon distribution across a series of samples (Simpson et al., 2011). For the vegetation

269 samples 1024 transients (executions of the pulse sequence) were taken, however due to the

270 presence of paramagnetic material in the peat soil transients were increased to 4096 to

271 improve the signal to noise ratio. Magic angle spinning (MAS) spin rate was set at $10 \mathrm{kHz}$ to

272 shift spinning side bands out of the region of interest and all signals were externally referenced

273 to adamant. The aromatic peak between $110-140$ ppm was integrated and its percentage of

274 the total signal calculated to give an indication of the differences between relative aromaticity

275 between samples (Peuravuori et al., 2003), which can be used as an alternative qualitative

276 measure of the recalcitrance of the litter (see Table 1). For further reading on using NMR

277 analysis for environmental research, see Simpson et al. (2011). 


\subsection{Statistical analysis}

All statistical analyses were carried out using R version 3.0.2 (R Core Team, 2015) and

281 plots were generated using the ggplot2 package (Wickham, 2009). The experiment involved a

282 three-way analysis of variance (ANOVA) design where temperature, rainfall and substrate

283 were the experimental factors. The effect of these factors, and their interaction, on response

284 variables of $\mathrm{CO}_{2}$ flux, mass loss, $\mathrm{DOC}$ leached and $\mathrm{CO}_{2}: \mathrm{DOC}$ ratio production was analysed

285 (Table 2). A Fligner-Killeen test was performed to determine that there was equal variance

286 between groups, and residuals were checked for normality. Carbon dioxide flux, DOC flux and

$287 \mathrm{CO}_{2}$ :DOC ratio were all square-root transformed prior to inclusion, in order to meet the 288 assumption of normally distributed residuals. A critical value of $P=0.05$ was used for statistical

289 significance. For multiple comparisons, the Tukey honest significant differences (HSD) test was

290 used. The variance explained by each factor was estimated using omega-squared $\left(\omega^{2}\right)$, a test

291 which is suitable for estimating effect size from small sample sizes (Keselman, 1975).

293 3. Results

294 3.1. Variability of decomposition rates between different substrates

295 Decomposition was greatest for the Molinia samples and slowest for the peat samples

296 (Fig. 1). The same substrate rankings were evident in terms of the following: the estimated

297 cumulative $\mathrm{CO}_{2}$ flux (means ranged from $942.87 \mathrm{mgC} \mathrm{gC}^{-1}$ for Molinia to $41.26 \mathrm{mgC} \mathrm{gC}^{-1}$ for

298 peat; Fig. 1); the DOC flux (means ranged from $20.95 \mathrm{mgC} \mathrm{gC}^{-1}$ for Molinia to $1.07 \mathrm{mgC} \mathrm{gC}^{-1}$

299 for peat; Fig. 1); and the overall total measured mass loss (means ranged from $511.21 \mathrm{mgC}$

$300 \mathrm{gC}^{-1}$ for Molinia to $27.43 \mathrm{mgC} \mathrm{gC}^{-1}$ for peat; Fig. 2). Substrate was a significant explanatory

301 factor in the ANOVA for all of these response variables $(P<0.001$; Table 2). Post-hoc tests 
302 suggested significant differences in the order Molina $>$ Sphagnum $=$ Mixed litter $>$ Calluna $>$

303 peat for $\mathrm{CO}_{2}$ flux; Molinia $>$ Calluna = Mixed litter $>$ Sphagnum > peat for DOC flux; and Molinia

$304>$ Calluna $>$ Sphagnum $=$ Mixed litter $>$ peat for mass loss.

305 There was a steady decrease in $\mathrm{CO}_{2}$ release over the entire incubation period, for all

306 substrates and treatments. The decrease in $\mathrm{CO}_{2}$ flux was greatest for the Molinia samples,

307 with a reduction in estimated flux between the first (day 1 to 30) and second half (day 31 to

30860 ) of the experiment of $64.27 \%$, compared to peat where the difference was $25.13 \%$ - the

309 lowest decline recorded.

310 In terms of total mass balance, the overall loss of $\mathrm{C}$ measured directly through mass

311 loss of the substrate and by the total fluxes $\left(\mathrm{DOC}+\mathrm{CO}_{2}\right)$ were not equal. Whilst DOC fluxes

312 were less than the total mass loss, the cumulative $\mathrm{CO}_{2}$ flux estimated by integration across the

313 experimental period (sensu Neff and Hooper, 2002) was greater than the total mass loss.

\section{3.2. Carbon dioxide to DOC partitioning}

316 The cumulative flux of $\mathrm{CO}_{2}$ was greater than DOC for all of the samples (Fig. 1). Mean

$317 \mathrm{CO}_{2}: \mathrm{DOC}$ quotients ranged from 31.56 for Molinia to 68.67 for Sphagnum (all climate

318 treatments pooled), indicating that proportionally more carbon was lost as DOC from Molinia

319 than Sphagnum. Substrate was again the strongest factor explaining the variation in 320 partitioning between gaseous and aquatic fluxes $(P<0.001)$. There was a significant

321 relationship between total $\mathrm{CO}_{2}$ flux and $\mathrm{DOC}$ leached between groups when all data were 322 pooled, indicating that DOC leaching increases with $\mathrm{CO}_{2}$ flux. However, this relationship was 323 not observed within substrate groups.

324 The general trend was for an increase in the $\mathrm{CO}_{2}: \mathrm{DOC}$ quotient under UKCP09 future 325 climate scenarios (Fig. 1). There was a statistically significant interaction between rainfall and 
326 substrate $(P<0.001)$, with the proportion of $\mathrm{C}$ lost as $\mathrm{CO}_{2}$ generally increasing under the

327 UKCP09 (drier) rainfall scenario. Post-hoc tests revealed that drier conditions were only

328 significant in changing the partitioning between gas and aquatic carbon fluxes for the peat $(P$

$329<0.001)$ and Sphagnum $(P<0.001)$ samples, the mean of which increased from $24.91( \pm 5.74)$

330 to $78.64( \pm 13.85)$ and from $47.34( \pm 2.41)$ to $101.78( \pm 16.25)$ when comparing the baseline

331 temperature and rainfall to the UKCP09 temperature and rainfall treatments. Partitioning

332 between $\mathrm{CO}_{2}$ and $\mathrm{DOC}$ in other substrates, Molinia, Calluna and mixed litter, was unaffected

333 by temperature and rainfall treatments $(P>0.05)$.

335 3.3. Relative importance and interaction between temperature and rainfall in controlling 336 decomposition

337 Increasing temperature had a significant effect on decreasing DOC flux $(P<0.001)$ and 338 increasing mass loss $(P<0.001)$. In addition, significant interactions between temperature and 339 substrate $(P<0.001)$ and rainfall and substrate $(P=0.001)$ were seen for DOC flux and for 340 mass loss $(P=0.007$ and $P=0.035$, respectively), indicating that the effect of simulated climate 341 change depended on substrate type. For DOC, post hoc tests suggested that the interaction 342 was only significant between temperature and Calluna, whereas for rainfall, there was a 343 significant interaction between rainfall treatment and Calluna and rainfall treatment and 344 Sphagnum. This interaction between rainfall and substrate was not unidirectional, however, 345 with the drier rainfall treatment increasing DOC in Calluna samples, but decreasing it in 346 Sphagnum. With mass loss, only Sphagnum was close to being significant on its own.

347 Differences in cumulative $\mathrm{CO}_{2}$ flux between climate treatments (both temperature and 348 rainfall) were non-significant $(P>0.05)$, though rainfall was close to the critical threshold $(P=$ 
349 0.075). No significant interaction between temperature and rainfall for any of the measures

350 of decomposition was observed ( $\mathrm{CO}_{2}$ flux, DOC flux or mass loss).

351

352 4. Discussion

353 4.1. Carbon fluxes and decomposition rates between different substrates

354 The fluxes of $\mathrm{CO}_{2}$ and $\mathrm{DOC}$, and the mass loss, were lowest from the peat samples 355 compared to litter sources, consistent with previous work (Moore and Dalva, 2001; Tang et

356 al., 2013). Decomposition in peatland ecosystems progresses along a continuum from freshly

357 senesced plant litter to peat. Part of the reason that peat decomposes more slowly than fresh

358 litter is because more labile compounds are preferentially utilised by decomposers (Wieder

359 and Lang, 1982). This results in older peat being composed of progressively more recalcitrant

360 materials (Broder et al., 2012). In the field, these differences are likely to be even greater as

361 decomposition of peat is further inhibited by anoxic and acidic conditions which prevail for

362 longer at greater depths. Here, we used measures of C:N ratio and aromaticity to characterise

363 the quality of the substrates. A high C:N ratio usually suggests recalcitrant litter, as $\mathrm{N}$ is limiting

364 for microbes and can also stimulate the activity of certain enzymes (Bragazza et al., 2012).

365 Here peat had the lowest C: $\mathrm{N}$ ratio, which could be due to retention of $\mathrm{N}$ containing

366 compounds during the decomposition process (Kalbitz and Geyer, 2002). Aromaticity is

367 another potential measure of decay resistance as aromatic polymers are characterised by

368 structural and chemical recalcitrance. In this instance, peat had the highest estimated

369 proportion of aromatic compounds (Table 1), which could in part explain its low 370 decomposition rate relative to the other substrates. 
372 observations of high retention of carbon in this species (Fenner et al., 2004). Sphagnum also

373 produced slightly more $\mathrm{CO}_{2}$ than Calluna, which was unexpected given the well documented

374 recalcitrance of Sphagnum litter which has been shown to decompose much more slowly than

375 other peat forming vegetation (van Breemen, 1995). This could have been a result of

376 environmental conditions, specifically water content, as the poor water holding capacity of

377 Calluna litter meant that lack of water supply could have limited its decomposition during

378 laboratory simulation experiments (Blok et al., 2015; Toberman et al., 2008).

379 The estimates of cumulative $\mathrm{CO}_{2}$ flux were approximately double the amount 380 estimated from $\mathrm{C}$ mass loss, suggesting an overestimation of cumulative $\mathrm{CO}_{2}$ flux by 381 integrating point measurements recorded here. This could partly be due to the measurement 382 of some autotrophic respiration from peat roots in the earlier stages of the experiment, or an 383 inadequate representation of night-time respiration rates. However, given that all samples 384 were treated in the same way, and were well mixed to begin with, it is reasonable to assume 385 that the observed differences between groups are robust.

\section{4.2. Relative importance of gaseous and fluvial fluxes}

388 The release of DOC during organic matter decomposition to surface waters is an 389 important component of the peatland carbon budget (Billett et al., 2010). Little is known 390 about partitioning between $\mathrm{CO}_{2}$ and DOC fluxes in peatlands (Bonnett et al., 2006). Herein, it 391 was shown that Molinia produced the most DOC as a proportion of its starting mass, and peat

392 produced the least. However, in terms of the ratio of $\mathrm{CO}_{2}$ to DOC, Calluna and mixed litter had 393 the lowest ratios, signalling that a higher proportion of mass is lost as $\mathrm{DOC}$ than $\mathrm{CO}_{2}$ for these 394 substrates, when compared with the others. Again, absolute values for $\mathrm{CO}_{2}: \mathrm{DOC}$ may not be 
395 accurate due to overestimation of measured $\mathrm{CO}_{2}$ fluxes, but comparisons between groups

396 should still be robust.

397 Previous studies have reported DOC fluxes equivalent to over $20 \%$ of net ecosystem 398 exchange (NEE) (e.g. Dinsmore et al., 2010; Koehler et al., 2011). In some instances, DOC 399 exported to streams has been estimated to exceed NEE (Billett et al., 2004), highlighting the 400 importance of including this flux when estimating source/sink status of a peatland. Strong 401 correlations have been found between gross primary productivity (GPP) and DOC 402 concentrations in peatland catchments (Dinsmore et al., 2013; Harrison et al., 2008), 403 suggesting a large amount of DOC is produced directly by living plants, indirectly by 404 rhizosphere priming or by the decay of fresh plant litter. The difference in the amount of DOC 405 released from the peat and litter samples in this study during decomposition supports the 406 theory that the decay of fresh litter is a substantive DOC source (Evans et al., 2007; Palmer et 407 al., 2001). In the field, a lot will depend on the regulating effect of water table depth on 408 decomposition, flow pathways of runoff (Wallage and Holden, 2011), as well as substrate.

409 We observed a lower DOC flux but no significant change in $\mathrm{CO}_{2}$ flux under the UKCP09 410 (warmer) temperature scenario. Combined with the lower DOC flux under UKCP09 (drier) 411 rainfall scenario for some of the substrates (Sphagnum), this resulted in an increase in the 412 partitioning coefficient between $\mathrm{CO}_{2}$ and DOC flux for some of the substrates (Sphagnum and 413 peat), which is in accordance with the findings of Neff and Hooper (2002) in their arctic soil 414 samples. This implies that a greater proportion of $\mathrm{C}$ released from Sphagnum and peat would 415 be lost in the form of $\mathrm{CO}_{2}$ than DOC under warmer and drier conditions, with the effect of 416 rainfall being slightly stronger than temperature. The strength of the rainfall effect suggests 417 that it is due more to the decreased flux of DOC than due to a reduction in total 418 decomposition. The total DOC measured in this study was in effect net DOC production; a 
419 function of release and transport, as well as its mineralisation. The decreased DOC flux could

420 be explained by a suppression of DOC mobility by drought-induced acidification (Clark et al.,

421 2006; Clark et al., 2012). DOC production could be affected by both microbial enzymatic

422 activity and physical leaching. It could be that DOC was produced, but lack of water supply

423 limited physical leaching and so it was subsequently consumed by microbes present in the

424 samples (Moore and Dalva, 2001). The findings presented here, that $\mathrm{CO}_{2}: \mathrm{DOC}$ partitioning

425 from Sphagnum and peat could be affected by climate change, but that the partitioning from

426 other substrates was not affected, will be of interest to those modelling the response of

427 peatland $\mathrm{C}$ balance as it indicates that DOC flux cannot be estimated from ecosystem 428 respiration alone. It is also useful information for water treatment engineers who are trying

429 to plan future climate-proof investments in treatment works, as these results imply that DOC

430 could increase or decrease in the future, depending on the proportion of different plant

431 species in the catchments, and the pattern of rainfall.

433 4.3. Effects and interactions between temperature and rainfall

434 Results indicate that simulated temperature changes have a greater effect on the loss

435 of DOC (generally decreasing the flux) and on mass loss (generally increasing the flux) than on 436 the production of $\mathrm{CO}_{2}$. The effect varied between substrates, for example, drier conditions 437 increased the DOC flux from Calluna, but decreased it from Sphagnum. When looking at the 438 main drivers of increased decomposition in peatlands, other laboratory based studies have 439 also found mixed results. Higher temperatures led to increased mass loss (between 5, 10 and $44015^{\circ} \mathrm{C}$ ) in a one year incubation of Scots pine needles below a living moss layer (Domisch et al., 441 2006), supporting the results found here. Neff and Hooper (2002) also found that temperature 442 controlled the $\mathrm{CO}_{2}$ flux from their incubated soil samples, but the response depended largely 
443 on vegetation community. However, in their study on DOC production across a range of spatial

444 scales, Preston et al. (2011) found that temperature had no effect on DOC production in their

445 peat microcosm experiment, regardless of moisture treatment. This contrasts with Clark et al.

446 (2006) who found increased DOC release at $20^{\circ} \mathrm{C}$ relative to $10^{\circ} \mathrm{C}$ in another laboratory study

447 incubating peat mesocosms.

448 Whilst measured mass loss did increase positively with temperature, measured $\mathrm{CO}_{2}$

449 fluxes did not. Investigations at lower temperatures than those used here have suggested

450 Sphagnum becomes more productive, growing faster, with increases in temperature from a

451 low base (Breeuwer et al., 2008), but that the opposite can occur for warmer temperatures

452 (17.5 and $21.7{ }^{\circ} \mathrm{C}$ ) (Breeuwer et al., 2009). Results herein indicate that decomposition,

453 measured through mass loss, increased with temperature, suggesting that the strength of the

454 peatland $\mathrm{C}$ sink could be reduced during summer months.

455 Rainfall treatment was just above the $P=0.05$ critical threshold for cumulative $\mathrm{CO}_{2}(P$ $456=0.075)$ and DOC flux $(P=0.070)$, with lower values seen under the UKCP09 (lower rainfall) 457 conditions. For DOC in peat, this agrees with the findings of Tang et al. (2013) who found that 458 DOC export was greater in the wetter treatments, and declined in the drought treatments.

459 Observed responses of DOC export to drought or experimentally lowered water tables have 460 been varied, with suggestions that DOC export could increase due to drought (Worrall et al., 461 2006). However, there are mechanisms which could explain the decrease in DOC observed 462 here. Decreased DOC during droughts could be due to a suppression of DOC transport by 463 drought-induced decrease in DOC solubility (Clark et al., 2012, 2006), or an increase in 464 hydrophobicity (Worrall et al., 2008) rather than a change in the production of DOC through 465 organic matter decomposition. A difference here is that this study simulated rainfall whereas 
466 those examining the mechanisms have tended to focus on water table effects, either through

467 manipulations in the laboratory or event-based analysis in the field.

468

469 4.4. Limitations of the study

470 The data presented here are a useful indication of the relative importance of different

471 substrates as sources of $\mathrm{DOC}$ and $\mathrm{CO}_{2}$ fluxes, decomposition and the potential for changes in 472 partitioning between $\mathrm{CO}_{2}$ and $\mathrm{DOC}$ under future climate conditions. However, these are

473 laboratory based simulation experiments and are subject to constraints that must be taken

474 into account when interpreting the results. Samples may have been exposed to more extreme

475 drying conditions than under field conditions as moisture levels were not regulated by living 476 vegetation and/or underlying water table, and the lack of a peat substrate beneath the 477 samples from the vegetation groups could also have increased the loss of water and so 478 negated any rainfall treatment effect. Ritson et al. (2017) found that any exposure to oxygen 479 (during laboratory experiments) increased DOC from peat and changed the quality of the C.

480 The differences with the results presented here suggest a high sensitivity to the amount and 481 frequency of the rainfall treatments. The findings of these laboratory experiments now need 482 to be tested under field conditions.

484 4.5. Wider implications for our understanding of peatland carbon balances

485 While predictions about future rainfall patterns are variable, with both increases and 486 decreases projected for northern latitudes (IPCC, 2014), models are in strong agreement that 487 temperatures at mid-to-high latitudes will increase due to climate change (Murphy et al., 488 2009), and that drought events are likely to become more frequent (Meehl and Tebaldi, 2004). 
489 While there are differences in both magnitude and direction of change between the 490 substrates, the data here suggest that warmer summer temperatures and decreased rainfall

491 could increase overall decomposition, reduce the flux of DOC, and subsequently alter the 492 partitioning of carbon released during decomposition from $\mathrm{DOC}$ to $\mathrm{CO}_{2}$.

493 Other studies have suggested that the effect of climate change will be more through

494 indirect effects on the composition of vegetation, with graminoids and dwarf shrubs being

495 favoured over Sphagnum mosses in warmer, drier conditions (Kapfer et al., 2011; Weltzin et

496 al., 2003). Given the greater lability of the litter produced by these plant functional types, seen

497 here in the greater decomposition of the Molinia samples, this could be a concern for climate 498 change mitigation. However, in SW England, where these samples were collected, graminoids 499 (Molinia) are already highly prevalent (Chambers et al., 1999) and so the effect may not be as 500 severe, as climate-induced vegetation change may already have occurred. The shallow peat in 501 this area suggests the area could have been sequestering $C$ at a lower rate than other blanket 502 peatlands, or even losing $C$, though further work looking at the entire $C$ balance is needed to 503 verify this.

504 In the field, it is likely that climate change may increase productivity, and therefore litter 505 production, alongside any increase in decomposition rates. Studies have already provided 506 evidence that warmer temperatures can increase rates of carbon sequestration at some 507 northern latitude peatlands, due in part to longer and warmer growing seasons enhancing 508 plant growth (Loisel and $\mathrm{Yu}, 2013$ ). Therefore, when interpreting the differences in 509 decomposition rates of the different substrates in the context of in situ actual conditions, it is 510 also important to consider their respective litter production rates and substrate supply (Ritson 511 et al., 2016). While Molinia showed the fastest decomposition in this experiment, it also tends 512 to produce more litter than Calluna (e.g. Aerts, 1989), so is likely to be a more significant 
513 source of $\mathrm{C}$ at the catchment scale. Also, while both substrates generally produce less "litter"

514 than Sphagnum (Bragazza et al., 2012), this may change in a warmer, drier climate (Breeuwer

515 et al., 2009). Further work is needed to take into account the effect of climate change on

516 productivity and litter production, as well as on decomposition, to assess the likely impacts of

517 climate change on the future carbon balance of peatlands.

519 5. Conclusions

$520 \quad$ This study has used short-term laboratory incubations of peat and peat-forming 521 vegetation from a climatically marginal blanket peatland in SW England in order to assess the 522 relative importance of different temperature and rainfall scenarios for the main $\mathrm{C}$ fluxes $\left(\mathrm{CO}_{2}\right.$ 523 and DOC) and their partitioning during short-term litter decay. The largest variation in C fluxes 524 and total mass loss was seen between substrates, with smaller fluxes (cumulative $\mathrm{CO}_{2}$ and $525 \mathrm{DOC}$ ) and mass lost from Sphagnum/peat compared to higher fluxes and mass loss from dwarf 526 shrub/graminoids. The $\mathrm{CO}_{2}: \mathrm{DOC}$ ratio was lowest for Molinia and highest for Sphagnum.

527 Climate factors were important too, but the effect depended largely on the substrate. For 528 example, while the future (drier) rainfall scenario increased the DOC flux from Calluna, it had 529 the opposite effect for Sphagnum. Therefore, indirect effects on species composition in 530 peatlands could ultimately turn out to be more important than direct effects of climate change

531 from increased temperatures and decreased rainfall.

532 Upscaling of this work from laboratory to field is needed in order to confirm these 533 laboratory-based findings and improve understanding of the likely impacts of climate change 534 on C fluxes and decomposition in peatlands. Further work across natural climatic gradients is 535 one way of addressing this research need, deploying a space for time substitution to 536 understand future climate change. 
538 This research was funded by a studentship received by Michael Bell from the Natural

539 Environment Research Council (grant number 1227376). Jonathan Ritson would like to

540 thank the Grantham Institute: Climate and Environment and Climate-KIC for financial

541 support. Brazier acknowledges the support of the South West Water-funded Mires-on-the-

542 Moors project. The authors would also like to thank South West Water and especially the

543 Mires project staff for access to sites as well as the Exmoor National Park Authoritiy. The

544 help of Dr Radek Kowalczyk of University of Reading for running the NMR experiments and

545 advising on their experimental design is also greatly appreciated.

548 References

549 1. Aerts, R., 1989. Aboveground Biomass and Nutrient Dynamics of Calluna vulgaris and 550 Molinia caerulea in a Aboveground biomass and nutrient dynamics of Callnna vulgaris $551 \quad$ and Molinia caerulea in a dry heathland. OIKOS 56, 31-38.

552 2. Billett, M., Charman, D., Clark, J., Evans, C., Evans, M., Ostle, N., Worrall, F., Burden, 553 A., Dinsmore, K., Jones, T., McNamara, N., Parry, L., Rowson, J., Rose, R., 2010.

554 Carbon balance of UK peatlands: current state of knowledge and future research $555 \quad$ challenges. Clim. Res. 45, 13-29. doi:10.3354/cr00903

556 3. Billett, M.F., Palmer, S.M., Hope, D., Deacon, C., Storeton-West, R., Hargreaves, K.J., 557 Flechard, C., Fowler, D., 2004. Linking land-atmosphere-stream carbon fluxes in a $558 \quad$ lowland peatland system. Global Biogeochem. Cycles 18, 1-12. doi:10.1029/2003GB002058

560 4. Blok, D., Elberling, B., Michelsen, A., 2015. Initial Stages of Tundra Shrub Litter 
Decomposition May Be Accelerated by Deeper Winter Snow But Slowed Down by Spring Warming. Ecosystems 19, 155-169. doi:10.1007/s10021-015-9924-3

5. Bonnett, S.A.F., Ostle, N., Freeman, C., 2006. Seasonal variations in decomposition processes in a valley-bottom riparian peatland. Sci. Total Environ., 370, 561-573.

6. Bragazza, L., Buttler, A., Habermacher, J., Brancaleoni, L., Gerdol, R., Fritze, H.,

8. Bragazza, L., Buttler, A., Siegenthaler, A., Mitchell, E.A.D., 2009. Plant Litter Biol. 18, 1163-1172. doi:10.1111/j.1365-2486.2011.02585.x

7. Bragazza, L., Buttler, A., Robroek, B.J.M., Albrecht, R., Zaccone, C., Jassey, V.E.J., Signarbieux, C., 2016. Persistent high temperature and low precipitation reduce peat carbon accumulation. Glob. Chang. Biol. 22, 4114-4123. doi:10.1111/gcb.13319 Decomposition and Nutrient Release in Peatlands, in: Baird, A.J., Belyea, L.R., Comas, X., Reeve, A.S., Slater, L.. (Eds.), Carbon Cycling in Northern Peatlands. American Geophysical Union, pp. 99-110.

9. Breeuwer, A., Heijmans, M.M.P.D., Gleichman, M., Robroek, B.J.M., Berendse, F., 2009. Response of Sphagnum species mixtures to increased temperature and nitrogen availability. Plant Ecol. 204, 97-111. doi:10.1007/s11258-009-9571-x 10. Breeuwer, A., Heijmans, M.M.P.D., Robroek, B.J.M., Berendse, F., 2008. The effect of temperature on growth and competition between Sphagnum species. Oecologia 156, 155-67. doi:10.1007/s00442-008-0963-8

11. Broder, T., Blodau, C., Biester, H., Knorr, K.H., 2012. Peat decomposition records in three pristine ombrotrophic bogs in southern Patagonia. Biogeosciences 9, 14791491. doi:10.5194/bg-9-1479-2012 

vegetation and carbon cycling in an ombrotrophic bog. Glob. Chang. Biol. 13, 11681186. doi:10.1111/j.1365-2486.2007.01346.x

13. Buttler, A., Robroek, B.J.M., Laggoun-Défarge, F., Jassey, V.E.J., Pochelon, C., Bernard, G., Delarue, F., Gogo, S., Mariotte, P., Mitchell, E.A.D., Bragazza, L., 2015. Experimental warming interacts with soil moisture to discriminate plant responses in an ombrotrophic peatland. J. Veg. Sci. 26, 964-974. doi:10.1111/jvs.12296 caerulea in environmentally sensitive areas : new perspectives from palaeoecological data. J. Appl. Ecol. 36, 719-733.

15. Clark, J., Gallego-Sala, A., Allott, T., Chapman, S., Farewell, T., Freeman, C., House, J., Orr, H., Prentice, I., Smith, P., 2010. Assessing the vulnerability of blanket peat to climate change using an ensemble of statistical bioclimatic envelope models. Clim. Res. 45, 131-150. doi:10.3354/cr00929

16. Clark, J.M., Chapman, P.J., Heathwaite, A.L., Adamson, J.K., 2006. Suppression of Dissolved Organic Carbon by Sulfate Induced Acidification during Simulated Droughts. Environ. Sci. Technol. 40, 1776-1783. doi:10.1021/es051488c in pore water during simulated drought cycles in six different UK peats. Biogeochemistry 109, 253-270. doi:10.1007/s10533-011-9624-9 drives a shift in peatland ecosystem plant community: Implications for ecosystem function and stability. Glob. Chang. Biol. 21, 388-395. doi:10.1111/gcb.12643 19. Dinsmore, K.J., Billett, M.F., Dyson, K.E., 2013. Temperature and precipitation drive 
temporal variability in aquatic carbon and GHG concentrations and fluxes in a peatland catchment. Glob. Chang. Biol. 19, 2133-48. doi:10.1111/gcb.12209 20. Dinsmore, K.J., Billett, M.F., Skiba, U.M., Rees, R.M., Drewer, J., Helfter, C., 2010. Role of the aquatic pathway in the carbon and greenhouse gas budgets of a peatland catchment. Glob. Chang. Biol. 16, 2750-2762. doi:10.1111/j.1365-2486.2009.02119.x of litter in peat soils from two climatic regions under different temperature regimes. Eur. J. Soil Biol. 42, 74-81. doi:10.1016/j.ejsobi.2005.09.017

22. Evans, C.D., Freeman, C., Cork, L.G., Thomas, D.N., Reynolds, B., Billett, M.F., Garnett, partitioning reveals that sphagnum photosynthate contributes to the DOC pool. Plant and Soil. 259, 345-354.

24. Fenner, N., Ostle, N.J., McNamara, N., Sparks, T., Harmens, H., Reynolds, B., Freeman, C., 2007. Elevated CO2 Effects on Peatland Plant Community Carbon Dynamics and DOC Production. Ecosystems 10, 635-647. doi:10.1007/s10021-007-9051-x

25. Frolking, S., Roulet, N.T., Tuittila, E., Bubier, J.L., Quillet, A., Talbot, J., Richard, P.J.H., 2010. A new model of Holocene peatland net primary production, decomposition, water balance, and peat accumulation. Earth Syst. Dyn. 1, 1-21. doi:10.5194/esd-1-12010

26. Freeman, C., Lock, M.A., Reynolds, B., 1993. Fluxes of carbon dioxide, methane and nitrous oxide from a Welsh peatland following simulation of water table draw-down: 
27. Gatis, N., Luscombe, D.J., Grand-Clement, E., Hartley, I.P., Anderson, K., Smith, D., Brazier, R.E., 2015. The effect of drainage ditches on vegetation diversity and CO2 fluxes in a Molinia caerulea-dominated peatland. Ecohydrology n/a-n/a. doi:10.1002/eco.1643

28. Gorham, E., 1991. Northern Peatlands: Role in the carbon cycle and probable responses to climatic warming. Ecol. Appl. 1, 182-195. R.E., 2013. Evaluating ecosystem goods and services after restoration of marginal

30. Grand-Clement, E., Luscombe, D.J., Anderson, K., Gatis, N., Benaud, P., Brazier, R.E., upland peatlands in South-West England. J. Appl. Ecol. n/a-n/a. doi:10.1111/13652014. Antecedent conditions control carbon loss and downstream water quality from 2664.12039

32. Holden, J., Burt, T.P., 2002. Infiltration, runoff and sediment production in blanket peat catchments: implications of field rainfall simulation experiments. Hydrol. Process. 16, 2537-2557. doi:10.1002/hyp.1014 
water: Fluxes and processes. Environ. Pollut. 84, 301-324.

34. IPCC, 2014. IPCC, 2014: Climate Change 2014: Synthesis Report. Contribution of Working Groups I, II and III to the Fifth Assessment Report of the Intergovernmental Panel on Climate Change [Core Writing Team, R.K. Pachauri and L.A. Meyer (eds.)]. Geneva, Switzerland.

35. Johnson, L.C., Damman, A.W.H., 1991. Species Controlled Sphagnum Decay on a South Swedish raised bog Sphagnum decay. Oikos 61, 234-242.

36. Kalbitz, K., Geyer, S., 2002. Different effects of peat degradation on dissolved organic carbon and nitrogen. Org. Geochem. 33, 319-326. doi:10.1016/S01466380(01)00163-2

38. Keselman, H.J., 1975. A Monte Carlo investigation of three estimates of treatment

37. Kapfer, J., Grytnes, J.-A., Gunnarsson, U., Birks, H.J.B., 2011. Fine-scale changes in

39. Keuskamp, J.A., Dingemans, B.J.J., Lehtinen, T., Sarneel, J.M., Hefting, M.M., 2013.

Tea Bag Index: a novel approach to collect uniform decomposition data across ecosystems. Methods Ecol. Evol. 4, 1070-1075. doi:10.1111/2041-210X.12097

40. Koehler, A.-K., Sottocornola, M., Kiely, G., 2011. How strong is the current carbon sequestration of an Atlantic blanket bog? Glob. Chang. Biol. 17, 309-319. doi:10.1111/j.1365-2486.2010.02180.x 
42. Limpens, J., Berendse, F., 2003. How litter quality affects mass loss and $\mathrm{N}$ loss from decomposing Sphagnum. Oikos 103, 537-547. doi:10.1034/j.16000706.2003.12707.x

43. Limpens, J., Berendse, F., Blodau, C., Canadell, J.G., Freeman, C., Holden, J., Roulet, N., Rydin, H., Schaepman-Strub, G., 2008. Peatlands and the carbon cycle: from local processes to global implications - a synthesis. Biogeosciences Discuss. 5, 1379-1419. doi:10.1029/2012JG001978

45. Luscombe, D.J., Anderson, K., Gatis, N., Grand-Clement, E., Brazier, R.E., 2015. Using 44. Loisel, J., Yu, Z., 2013. Recent acceleration of carbon accumulation in a boreal peatland, south central Alaska. J. Geophys. Res. Biogeosciences 118, 41-53. airborne thermal imaging data to measure near-surface hydrology in upland ecosystems. Hydrol. Process. 29, 1656-1668. doi:10.1002/hyp.10285

48. Moore, T.R., Dalva, M., 2001. Some controls on the release of dissolved organic carbon by plant tissues and soils. Soil Sci. 166, 38-47. 49. Moore, T.R., Paré, D., Boutin, R., 2008. Production of Dissolved Organic Carbon in Canadian Forest Soils. Ecosystems 11, 740-751. doi:10.1007/s10021-008-9156-x 50. Murphy, J.M., Sexton, D.M.H., Jenkins, G.J., Booth, B.B.B., Brown, C.C., Clark, R.T., Collins, M., Harris, G.R., Kendon, E.J., Betts, R.A., Brown, S.J., Humphrey, K.A., 
McCarthy, M.P., McDonald, R.E., Stephens, A., Wallace, C., Warren, R., Wilby, R., Wood, R.A., 2009. UK Climate Projections Science Report: Climate Change Projections.

51. Neff, J.C., Hooper, D.U., 2002. Vegetation and climate controls on potential CO2, DOC and DON production in northern latitude soils. Glob. Chang. Biol. 8, 872-884. doi:10.1046/j.1365-2486.2002.00517.x

52. Palmer, S.M., Hope, D., Billett, M.F., Dawson, J.J.C., Bryant, C.L., 2001. Sources of organic and inorganic carbon in a headwater stream: Evidence from carbon isotope studies. Biogeochemistry 52, 321-338. doi:10.1023/A:1006447706565

53. Parry, L.E., Charman, D.J., 2013. Modelling soil organic carbon distribution in blanket peatlands at a landscape scale. Geoderma $211-212,75-84$. doi:10.1016/J.GEODERMA.2013.07.006

54. Pastor, J., Solin, J., Bridgham, S.D., Updegraff, K., Harth, C., Weishampel, P., Dewey,

56. Preston, M.D., Eimers, M.C., Watmough, S.A., 2011. Effect of moisture and

55. Peuravuori, J., Ingman, P. and Pihlaja, K., 2003. Critical comments on accuracy of quantitative determination of natural humic matter by solid state (13)C NMR spectroscopy. Talanta 59(1), 177-89. 

dissolved organic carbon release from peat and surface vegetation: Implications for drinking water treatment. Water Res. 67, 66-76. doi:10.1016/j.watres.2014.09.015 59. Ritson, J.P., Bell, M., Brazier, R.E., Grand-Clement, E., Graham, N.J.D., Freeman, C., Smith, D., Templeton, M.R., Clark, J.M., 2016. Managing peatland vegetation for drinking water treatment. Scientific Reports. 6, 36751.

60. Ritson, J.P., Brazier, R.E., Graham, N.J.D., Freeman, C., Templeton, M.R., Clark, J.M., 2017. The effect of drought on dissolved organic carbon (DOC) release from peatland soil and vegetation sources. Biogeosciences 14, 2891-2902. doi:10.5194/bg-14-28912017

61. Rodwell, J., 1991. British pant communities, Vol 2: mires and heaths. Cambridge Univeristy Press, Cambridge.

62. Simpson, A.J., McNally, D.J., Simpson, M.J., 2011. NMR spectroscopy in environmental research: From molecular interactions to global processes. Prog. Nucl. Magn. Reson. Spectrosc. 58, 97-175. doi:10.1016/j.pnmrs.2010.09.001

63. Smith, J., Gottschalk, P., Bellarby, J., Chapman, S., Lilly, A., Towers, W., Bell, J., Coleman, K., Nayak, D., Richards, M., Hillier, J., Flynn, H., Wattenbach, M., Aitkenhead, M., Yeluripati, J., Farmer, J., Milne, R., Thomson, A., Evans, C., Whitmore, effects of water table drawdown on above- and belowground plant litter decomposition: consequences for accumulation of organic matter in boreal 
peatlands. Glob. Chang. Biol. 18, 322-335. doi:10.1111/j.1365-2486.2011.02503.x

65. Tang, R., Clark, J.M., Bond, T., Graham, N., Hughes, D., Freeman, C., 2013.

Assessment of potential climate change impacts on peatland dissolved organic carbon release and drinking water treatment from laboratory experiments. Environ. Pollut. 173, 270-277.

R.R.E., 2008. Summer drought effects upon soil and litter extracellular phenol oxidase activity and soluble carbon release in an upland Calluna heathland. Soil Biology \& Biochemistry 40, 1519-1532.

67. Turetsky, M.R., 2003. The Role of Bryophytes in Carbon and Nitrogen Cycling. Bryologist 106, 395-409.

68. van Breemen, N., 1995. How Sphagnum bogs down other plants. Trends Ecol. Evol. $10,270-275$.

69. Wallage, Z.E., Holden, J., 2011. Near-surface macropore flow and saturated hydraulic conductivity in drained and restored blanket peatlands. Soil Use Manag. 27, 247-254. doi:10.1111/j.1475-2743.2011.00336.x

70. Weltzin, J.F., Bridgham, S.D., Pastor, J., Chen, J., Harth, C., 2003. Potential effects of warming and drying on peatland plant community composition. Glob. Chang. Biol. 9, 141-151. doi:10.1046/j.1365-2486.2003.00571.x

71. Wickham, H., 2009. ggplot2: elegant graphics for data analysis. Springer, New York. 10, 1323-1340. doi:10.1007/s10021-007-9101-4 73. Wieder, R.K., Lang, G.E., 1982. A Critique of the Analytical Methods Used in 

Hesse, S., Abbt-Braun, G., Frimmel, F.H., 2002. Fractionation of natural organic matter in drinking water and characterization by $13 \mathrm{C}$ cross-polarization magic-angle spinning NMR spectroscopy and size exclusion chromatography. Environ. Sci. Technol. 36, 3497-503. doi:10.1021/es010975z runoff of DOC from peat soils - The use of an event analysis. J. Hydrol. 358, 84-95. 
801 Tables and figure captions

802 Table 1. Organic matter properties for peatland vegetation and peat classes used in the

803 experiment. Values are means $(n=5)$ of subsample values, numbers in brackets are the

804 standard error of the mean. Aromaticity is a qualitative measure and was calculated from

805 cross polarization-magic angle spinning nuclear magnetic resonance (CP-MAS NMR).

\begin{tabular}{|c|c|c|c|c|c|c|}
\hline Class & $\begin{array}{l}\text { Dominant } \\
\text { substrate }\end{array}$ & $\mathrm{C}(\%)$ & $\mathrm{N}(\%)$ & $\mathrm{C}: \mathrm{N}$ ratio & 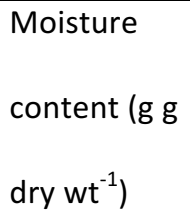 & $\begin{array}{l}\text { Aromaticity } \\
(\%)\end{array}$ \\
\hline Calluna & Calluna vulgaris & $49.3(0.02)$ & $1.35(0.01)$ & $36.4(0.22)$ & $1.90(0.01)$ & 8 \\
\hline Mixed litter & Senesced Molinia c & $45.9(0.01)$ & $1.29(0.01)$ & $35.6(0.28)$ & $5.38(0.11)$ & 5 \\
\hline Molinia & Molinia caerulea & $45.5(0.02)$ & $2.34(0.02)$ & $19.5(0.13)$ & $3.56(0.05)$ & 5 \\
\hline Peat & Peat & $29.1(0.02)$ & $1.64(0.01)$ & $17.7(0.07)$ & $6.06(0.06)$ & 11 \\
\hline Sphagnum & Sphagnum spp. & $41.8(0.03)$ & $1.00(0.01)$ & $42.1(0.28)$ & 15.020.15) & 7 \\
\hline
\end{tabular}

806

807

808

809

810

811

812

813

814

815

816 
817 Table 2. ANOVA model results, where the model fitted is response $=$ Temperature $*$ Rainfall $*$

818 Substrate (Cumulative $\mathrm{CO}_{2}, \mathrm{DOC}$ and $\mathrm{CO}_{2}$ :DOC ratio are square-root transformed data).

819 Significant differences $(P<0.05)$ are highlighted in bold and effect sizes $\left(\omega^{2}\right)$ are stated in

820 brackets. "Temp", "Rain" and "Sub" are short for Temperature, Rainfall and Substrate,

821 respectively).

\begin{tabular}{lllll}
\hline Variable & Factor & $\boldsymbol{F}$ & df & $\boldsymbol{P}$ value \\
\hline Cumulative $\mathrm{CO}_{2}$ & Temperature & 1.04 & 1 & 0.311 \\
$\left(\mathrm{mgCO}_{2}-\mathrm{CgC}^{-1}\right)$ & Rainfall & 3.25 & 1 & 0.075 \\
& Substrate & 631.08 & 4 & $<\mathbf{0 . 0 0 1}(0.960)$ \\
& Temp:Rain & 0.06 & 1 & 0.804 \\
& Temp:Sub & 1.27 & 4 & 0.288 \\
& Rain:Sub & 1.68 & 4 & 0.164 \\
& Temp:Rain:Sub & 1.27 & 4 & 0.290 \\
& & & & \\
Mass loss $\left._{\left(\mathrm{mgCO}_{2}-\mathrm{CgC}\right)}^{-1}\right)$ & Temperature & 20.10 & 1 & $<\mathbf{0 . 0 0 1}(0.005)$ \\
& Rainfall & 0.01 & 1 & 0.927 \\
& Substrate & 946.23 & 4 & $<\mathbf{0 . 0 0 1}(0.966)$ \\
& Temp:Rain & 0.01 & 1 & 0.915 \\
& Temp:Sub & 3.80 & 4 & $\mathbf{0 . 0 0 7}(0.003)$ \\
& Rain:Sub & 2.72 & 4 & $\mathbf{0 . 0 3 5}(0.002)$ \\
$\left.\mathrm{DOC}_{\left(\mathrm{mgCO}_{2}-\mathrm{CgC}\right.}^{-1}\right)$ & Temp:Rain:Sub & 0.56 & 4 & 0.690 \\
& & & & \\
& Temperature & 18.19 & 1 & $<\mathbf{0 . 0 0 1}(0.015)$ \\
& Rainfall & 3.38 & 1 & 0.070 \\
& Substrate & 247.14 & 4 & $<\mathbf{0 . 0 0 1}(0.838)$ \\
& Temp:Rain & 0.04 & 1 & 0.837 \\
$\mathrm{CO}_{2}-\mathrm{C}: \mathrm{DOC}^{-\mathrm{C}}$ & Temp:Sub & 5.12 & 4 & $\mathbf{0 . 0 0 1}(0.014)$ \\
& Rain:Sub & 11.34 & 4 & $<\mathbf{0 . 0 0 1}(0.035)$ \\
& Temp:Rain:Sub & 4.43 & 4 & $\mathbf{0 . 0 0 3}(0.012)$ \\
& Temperature & 15.57 & 1 & $<\mathbf{0 . 0 0 1}(0.056)$ \\
& Rainfall & 26.16 & 1 & $<\mathbf{0 . 0 0 1}(0.097)$ \\
& Substrate & 19.96 & 4 & $<\mathbf{0 . 0 0 1}(0.292)$ \\
& Temp:Rain & 0.01 & 1 & 0.921 \\
& Temp:Sub & 3.27 & 4 & $\mathbf{0 . 0 1 5}(0.035)$ \\
& Rain:Sub & 8.71 & 4 & $<\mathbf{0 . 0 0 1}(0.119)$ \\
& Temp:Rain:Sub & 2.24 & 4 & $\mathbf{0 . 0 7 2}$ \\
\hline & & &
\end{tabular}

822 
824 Figure 1. Treatment effects on measures of carbon fluxes, and their ratio; (a) Cumulative $\mathrm{CO}_{2}$

825 flux, (b) DOC flux, (c) Cumulative $\mathrm{CO}_{2}$ to DOC ratio (Error bars indicate one standard error).

826 Different letters denote statistically significant differences in means between substrates and

827 asterisks denote significant differences between treatments for substrates based on Tukey

828 HSD test $(P<0.05)$.

829

830 Figure 2. Treatment effects on $\mathrm{C}$ loss estimated from mass and $\mathrm{C}$ quotient measurements

831 (Error bars indicate one standard error). Different letters denote statistically significant

832 differences in means between substrates and asterisks denote significant differences

833 between treatments for substrates based on Tukey HSD test $(P<0.05)$.

834

835 